\title{
PENGEMBANGAN MODEL REKONSTRUKSI PENDIDIKAN PADA BAHAN AJAR SEL ELEKTROKIMIA BERBASIS GREEN CHEMISTRY
}

\author{
Eka Yusmaita ${ }^{1)}$ Ahmad Mudzakirir ${ }^{2)}$ Hernani $^{3)}$ \\ ${ }^{1)}$ Staf Pengajar Jurusan Kimia, FMIPA Universitas Negeri Padang \\ ${ }^{2}$ Staf Pengajar Jurusan Kimia, FMIPA Universitas Pendidikan Indonesia \\ ${ }^{3)}$ Staf Pengajar Jurusan Kimia, FMIPA Universitas Pendidikan Indonesia \\ ekayusmaita@gmail.com
}

\begin{abstract}
This study aimed to analyze the construction of teaching materials which are relevant to daily life using the theme of green batteries. The method used the model of educational reconstruction as a framework. This model consisted of three components, which are: analysis of content structure, research on teaching and learning, and development of learning settings. The discussion in this study was focused only on the analysis of content structure which required three stages, they are: analysis of literature, clarification of basic context, and modification of the text. First stage would produce indicators and learning objectives for cognitive and affective domains, which were based on the content of electrochemistry cells, the context of Li-ion batteries, and the scientific literacy. Second stage was the elementarization process of elektrokimiaic cell content and Li-ion batteries context. Third stage was the process of insertion and abolition of original text to become basic text. Validation through expert judgments was conducted for indicators and learning objectives of cognitive and affective domains based on the Standard of Competence, Basic Competence and competencies in PISA 2009.
\end{abstract}

Keywords : Model of Educational Reconstruction, Teaching Material, Electrochemistry Cell, Green Chemistry

\section{PENDAHULUAN}

Berdasarkan kongres IUPAC (Tundo, 2001) Green chemistry pada konteks saintifik adalah penerapan sejumlah kaidah fundamental kimia untuk mengurangi pemakaian atau memproduksi bahan kimia yang berbahaya. Green Chemistry bertujuan untuk mencegah atau mengurangi bahaya polusi pada segala jalur timbulnya polusi tersebut. Pada area pendidikan, green chemistry muncul sebagai solusi dalam menjawab kebutuhan ini (Cann, 2009). Masyarakat baru menyadari pentingnya melestarikan lingkungan sekitar, setelah ada dampak/resiko yang muncul akibat pencemaran. Paradigma ini harus segera dirubah. Sebagai generasi penerus bangsa kita harus mampu memberikan solusi yang cerdas sebelum resiko itu muncul akibat dari ketidak pedulian kita terhadap lingkungan. Salah satu caranya adalah melakukan suatu tindakan preventif dengan meminimalisir resiko yang akan terjadi kedepannya melalui green chemistry.

Penerapan konsep green chemistry biasanya diterapkan di laboratorium, Meskipun demikian pengintegrasiannya tidak harus terfokus pada laboratorium (Klingshirn, 2009). Cann (2009) dalam penelitiannya memberikan rekomendasi kepada para pendidik untuk menginte- grasikan konsep green chemistry di dalam bahan ajar. Berdasarkan studi pendahuluan pada salah satu sekolah Adiwiyata di kota Bandung, diketahui bahwa bahan ajar yang berbasis green chemistry belum tersedia.

Proses penyusunan bahan ajar merupakan proses yang tidak mudah dan sederhana. Penyusunan bahan ajar membutuhkan proses penyeleksian dari berbagai sumber yang dapat terpercaya dan kesediaan para pakar untuk mereview bahan ajar tersebut. Meskipun beberapa materi ajar yang berhubungan dengan green chemistry telah tersedia, namun sebagian besar materi ajar ini belum diterjemahkan dalam bahasa Indonesia. Untuk itu perlu pemikiran dan penelitian yang serius dan mendalam tentang penyusunan bahan ajar ini agar dapat memenuhi kriteria accessible bagi siswa.

Bahan ajar yang berkembang di Indonesia cenderung menempatkan konten terlebih dahulu dan diakhiri dengan aplikasi dari konten tersebut. Hal ini tidak sejalan dengan pendapat Holbrook (2005) yang menyatakan bahwa sains harus relevan dengan proses dan produk seharihari yang digunakan dalam masyarakat. Sebagai sinkronisasinya, saat melakukan penyusunan bahan ajar yang relevan dengan kehidupan sehari-hari, maka disesuaikan dengan Science Tech- 
nology and Literacy (STL) yang memodifikasi tahapan-tahapan pembelajaran berdasarkan proyek chemie in kontext dalam Nentwig et al (2002). Tujuan singkronisasi ini adalah untuk mengembangkan kreatifitas siswa, siswa mampu untuk memecahkan masalah dan membuat keputusan yang dapat meningkatkan mutu kehidupan (Holbrook. 2005)

Konsep Green chemistry menyediakan peluang untuk mendidik generasi ke depan menuju sustainable society (Klingshirn, et al. 2009). Green chemistry berperan penting dalam pembangunan berkelanjutan (sustainable development). Brundtland dalam (Holbrook, 2009) mendefinisikan pembangunan berkelanjutan sebagai pembangunan yang memenuhi kebutuhan sekarang tanpa meragukan kemampuan generasi mendatang untuk memenuhi kebutuhannya. Konsep pembangunan berkelanjutan memberikan himbauan bahwa pembangunan akan memungkinkan generasi sekarang meningkatkan kesejahteraan, tanpa mengurangi hak generasi masa depan untuk meningkatkan kesejahteraannya. ICASE (International Council of Association for Science Education) mengemukakan bahwa literasi sains dan teknologi erat kaitannya dengan isu pembangunan berkelanjutan (Holbrook, 2009). Terkait dengan kemampuan literasi sains peserta didik, studi penilaian yang dilakukan oleh PISA (Programme for International Student Assessment) mengungkapkan bahwa pembelajaran sains di Indonesia kurang berhasil meningkatkan kemampuan literasi sains peserta didik. Kekecewaan terhadap hasil monitoring PISA tersebut tidak bisa didiamkan begitu saja, perlu adanya suatu gagasan yang mendasar dan relevan. Rendahnya hasil PISA peserta didik Indonesia dan masalah lingkungan yang sering terjadi, merupakan tantangan masa depan dan menjadi alasan mengapa perlu adanya pembaharuan pada pengembangan kurikulum (Kemendikbud, 2012). Pada penelitian ini, pembaharuan itu dihubungkan dengan perancangan bahan ajar yang sesuai dengan kebutuhan siswa, yaitu bahan ajar yang memenuhi kriteria accessible bagi siswa.

Salah satu materi kimia yang memiliki potensi untuk dikembangkan melalui bahan ajar berbasis green chemistry education adalah konsep elektrokimia. Pemilihan konsep materi elektrokimia didasarkan pada pandangan PISA terkait dengan beberapa prinsip pemilihan konten sains PISA, yakni:
1. Konsep yang diujikan harus relevan dengan situasi kehidupan keseharian yang nyata.

2. Konsep itu diperkirakan masih akan relevan sekurang-kurangnya untuk satu dasawarsa ke depan.

3. Konsep itu harus berkaitan dengan kompetensi proses yaitu pengetahuan tidak hanya mengandalkan daya ingat siswa dan berkaitan hanya dengan informasi tertentu.

(Hayat dan Yusuf, 2010)

Selama ini, penyajian bahan ajar khususnya pada konsep elektrokimia belum relevan dengan proses dan produk sehari-hari yang digunakan dalam masyarakat. Di samping itu, contoh yang diberikan dari aplikasi sel elektrokimia masih terlalu umum dan menyajikan contoh-contoh dari baterai yang beracun (tidak ramah lingkungan). Oleh sebab itu dalam pengembangan bahan ajar ini difokuskan untuk memperkenalkan kepada siswa mengenai inovasi baterai yang ramah lingkungan, khususnya baterai Li-ion. Siswa perlu mengetahui bahwa teknologi mutakir kekinian seputar baterai. Berdasarkan uraian tersebut maka tujuan penelitian ini adalah mengembangkan model rekonstruksi pendidikan pada bahan ajar sel elektrokimia berbasis green chemistry.

\section{METODE PENELITIAN}

Desain penelitian ini menggunakan Model of Educational Reconstruction (MER) atau di Indonesia dikenal dengan istilah Model Rekonstruksi pendidikan. Model ini dikembangkan oleh Reinders Duit, Harald Gropengiesser, Ulrich Kattman dan Michael Komorek sejak tahun 1995 sampai sekarang. Tujuan utama perancangan MER adalah sebagai kerangka untuk penelitian dan pengembangan pendidikan sains. Disamping itu, MER juga dijadikan sebagai petunjuk untuk perencanaan pengajaran sains pada praktek di sekolah (Duit, 2012:19). Salah satu dari ide fundamental model ini adalah struktur konten untuk pengajaran tidak bisa diambil secara langsung dari struktur konten sains, tetapi secara khusus direkonstruksi dengan memperhatikan tujuan pembelajaran kognitif dan afektif siswa. Proses rekonstruksi terhadap bahan ajar digambarkan melalui tiga komponen MER berupa (1) analisis struktur konten, (2) penelitian mengajar dan belajar, dan (3) pengembangan dan evaluasi pelajaran. Ketiga komponen ini hubungannya yang saling berkaitan. (Duit, Komorek, \& Wilbers, 1997; Komorek \& Duit, 2004; Stavrou, Duit, \& Komorek, 2008). 
Komponen pertama adalah analisis struktur konten. Tujuan dari analisis struktur konten adalah untuk mengklarifikasi konsepsi sains yang spesifik dan struktur konten dari sudut pandang pendidikan. Komponen pertama ini dijabarkan lagi dalam dua proses, yaitu klarifikasi materi subjek dan analisis signifikansi pendidikan. Klarifikasi materi subjek menggambarkan analisis konten secara kualitatif terhadap buku teks yang berkualitas dan dari beberapa publikasi artikel. Analisis signifikansi pendidikan menggambarkan kaidah tertentu terhadap standar pedagogik dan tujuan pembelajaran (Duit, 2007: 8). Analisis kritis dari konten sains melalui pendidikan sains perlu dilakukan karena buku teks universitas diperuntukkan untuk para pakar (contohnya ilmuwan, atau mahasiswa yang menjadi ilmuwan). Bagi siswa di sekolah atau di tempat pembelajaran informal, penyajian konten secara ilmiah langsung dari buku teks universitas merupakan hal yang tidak dapat dijangkau (accessible) dan kadang-kadang menyesatkan. Oleh karena itu diperlukan suatu tindakan "penyederhanaan" (Duit, et al., 2012: 22).

Tindakan penyederhanaan penting dilakukan karena masih banyak bahan ajar baik keluasannya maupun kedalamannya yang belum sesuai dengan tingkat perkembangan siswa sehingga tidak mudah untuk dipahami oleh siswa. Anwar (2011:31) menawarkan suatu pendekatan dalam melakukan tindakan penyederhanaan bahan ajar, pendekatan ini disebut dengan reduksi didaktik. Mereduksi secara didaktis bahan ajar merupakan kegiatan yang terutama harus dilakukan oleh guru dalam mempersiapkan pengajarannya yang terstruktur dengan baik, sehingga dapat membantu siswa di dalam pengintegrasian informasi yang baru itu ke dalam struktur kognitif siswa. Di samping itu aksi ini sangat penting dilaksanakan melihat kenyataan bahwa beberapa materi pelajaran pada tingkat tertentu masih dirasakan terlalu tinggi (sukar) sehingga siswa merasakan "overloaded". Diharapkan dengan adanya reduksi terhadap bahan ajar didalam mempersiapkan kurikulum masa depan yang lebih berdasar pada pengalaman empiris dan kebutuhan masyarakat, dapat mengatasi masalah tersebut.

Ada delapan cara untuk mereduksi tingkat kesulitan bahan ajar dengan Reduksi Didaktik atau disingkat RD (Anwar, 2012: 17-19) :

\section{Kembali kepada tahapan kualitatif}

Suatu eksplanasi pedagogi ataupun eksplanasi ilmiah, jika dipresentasikan dalam bentuk data kuantitatif (angka-angka), hampir selalu dalam keadaan yang lebih kompleks dan sulit. Tetapi jika eksplanasi tersebut disajikan dalam bentuk kualitatif (kata-kata), maka orang akan lebih mudah memahami makna atau arti dari ekplanasi tersebut. Sebagai contoh bagaimana hasil percobaan (berupa data) untuk menentukan kecepatan suatu reaksi disajikan dalam bentuk tabel, yang jika orang membacanya perlu pengamatan dan interpretasi data untuk memahami arti data dalam tabel tersebut. Jika data dalam tabel itu disajikan dalam bentuk kata-kata yang sederhana, maka orang akan lebih mudah memahaminya.

\section{Pengabaian}

Hasil berbagai temuan ilmiah, baik yang dipresentasikan dalam ekplanasi ilmiah maupun eksplanasi pedagogik yang terdapat pada berbagai buku, biasanya telah mengalami berbagai pengabaian. Misalnya model atom Dalton yang mengatakan bahwa "atom berbentuk seperti bola pejal" merupakan hasil reduksi dari hasil temuan-temuan para ahli sebelumnya yang sangat kompleks dan rumit. Akan tetapi agar pemikirannya itu dapat dipahami oleh orang lain maka Dalton menyampaikannya seperti kalimat sederhana di atas. Atas dasar keterbatasan yang ada pada diri manusia, maka setiap penjelasan konsep-konsep keilmuan hampir selalu telah mengalami pengabaian.

3. Penggunaan penjelasan berupa gambar, simbol, sketsa, dan percobaan

Gambar merupakan wakil dari benda yang sebenarnya, ketika kita tidak dapat memperlihatkan benda yang sebenarnya. Penjelasan verbal yang kita berikan kapada orang lain akan lebih mudah difahami, jika dibantu dengan penjelasan berupa gambar.

Simbol digunakan jika benda atau penjelasan yang harus disampaikan kurang praktis atau memerlukan penjelasan yang panjang. Dengan simbol maka penjelasan yang panjang tersebut dapat diringkas sedemikian rupa, sehingga kompleksitas penjelasan dapat dikurangi.

Sketsa diperlukan untuk memberikan penjelasan praktis yang kompleks, karena penjelasan tersebut terdiri dari banyak komponen yang saling berhubungan. Dengan sketsa penjelasan tersebut dapat dibuat lebih sederhana. 
Percobaan (eksperimen) merupakan salah satu kegiatan yang spesifik dimiliki oleh mata pelajaran IPA. Dengan eksperimen siswa dibantu untuk memahami produk IPA. Dengan percobaan ini juga siswa dapat belajar dengan melakukan (learning by doing), sehingga pemahaman siswa terhadap suatu konsep dapat ditingkatkan.

\section{Penggunaan analogi}

Ilmu kimia merupakan ilmu yang sarat dengan konsep-konsep yang sangat abstrak. Untuk menjelaskan konsep yang abstrak tersebut dibutuhkan pendekatan yang mampu membuat yang abstrak tersebut menjadi relatif lebih konkret. Salah satu cara untuk itu adalah dengan penggunaan analogi. Analogi adalah pengibaratan suatu yang sulit dipahami dengan sesuatu yang mudah dipahami. Oleh sebab itu di dalam membuat analogi diharuskan analogi tersebut adalah apa yang pernah diketahui dan dikenal. Di dalam analogi, konsep yang akan dianalogikan disebut dengan konsep target, sedangkan analoginya sendiri disebut konsep analogi. Antara konsep analogi dengan konsep target harus memiliki atribut yang hampir sama, jika tidak, kesalahan konsep atau miskonsepsi dapat terjadi. Hal lain yang harus diperhatikan dalam membuat analogi adalah bahwa konsep analogi harus lebih sederhana dari pada konsep target.

5. Penggunaan tingkat perkembangan sejarah

Ilmu pengetahuan berkembang mulai dari konsep yang sederhana (saat itu tidak sederhana) hingga ilmu pengetahuan yang saat ini dipandang rumit. Penggunaan konsep-konsep yang sederhana (ilmu pengetahuan lama) akan membantu siswa di dalam memahami konsepkonsep yang saat ini disebut modern. Penggunaan jenis reduksi ini, memerlukan pembelajaran berkelanjutan, agar tidak terjadi miskonsepsi.

6. Generalisasi

Berbagai hasil pemikiran dan penelitian seluruhnya ditulis dalam bentuk kesimpulan (proses induksi) yang menggambarkan seluruh hasil pemikiran dan penelitian tersebut. Proses ini disebut sebagai generalisasi. Berbagai macam data yang dikumpulkan biasanya merupakan hal hal khusus yang jumlahnya cukup banyak. Jika data-data yang cukup banyak tersebut jika dipelajari oleh siswa, akan kelihatan betapa kompleks dan rumitnya informasi yang harus difahami oleh siswa dari data tersebut. Dengan membuat generalisasi dari data-data yang kompleks dan rumit ini maka informasi yang terkandung akan lebih mudah dipahami oleh siswa.

\section{Partikularisasi}

Suatu konsep yang kompleks dapat dibuat sederhana dengan partikularisasi. Partikularisasi adalah pemilahan informasi dari konsep yang memiliki informasi yang banyak (kompleks) menjadi bagian-bagiannya yang lebih sederhana. Sebagai contoh, sebuat tabel periodik unsurunsur yang memuat banyak sekali informasi, akan lebih sederhana dan mudah dipelajari dan difahami siswa, jika informasi tersebut dipilahpilah ke dalam setiap tabel periodik.

8. Pengabaian perbedaan pernyataan konsep

Cara reduksi ini diperlukan karena banyak istilah-istilah ilmiah yang pada kehidupan sehari hari banyak digunakan. Istilah-istilah ini begitu seringnya digunakan sehingga dipandang mudah oleh siswa. Penggunaan kata "panas" misalnya seringkali maksudnya adalah kalor, kata "zat" digunakan untuk benda, dan sebagainya. Istilahistilah ini masih boleh dipergunakan dalam pembelajaran selama hal itu tidak mengarah pada miskonsepsi.

Komponen kedua. Penelitian mengajar dan belajar mengidentifikasi bahwa proses klarifikasi dan analisis dari konten sains pada satu sisi dan proses konstruksi terhadap struktur konten untuk pengajaran pada sisi yang lain membutuhkan dasar penelitian empiris pada mengajar dan belajar. Studi empiris terhadap pengaturan belajar tertentu membutuhkan studi lebih lanjut dengan melakukan investigasi konsepsi pre-instructional siswa dan variabel afektif seperti ketertarikan, konsep diri, dan sikap (Duit, et al., 2012: 23)

Komponen ketiga. Perancangan dan evaluasi lingkungan pengajaran dan belajar komponen ini terdiri dari merancang bahan ajar, aktivitas pembelajaran dan sequence mengajar dan pembelajaran. Rancangan pembelajaran yang mendukung kondisi lingkungan sekitar merupakan jantung pada komponen ini (Duit, et al. 2012: 23).

Instrumen penelitian yang digunakan adalah lembar validasi pakar untuk menentukan kelayakan materi bahan ajar. Validator yang terlibat adalah sebanyak 7 orang panelis yang terdiri dari dosen dan guru kimia SMA. 
Lembar validasi dalam penelitian ini meliputi:

a. Lembar validasi indikator dan tujuan pembelajaran aspek kognitif melalui telaah konteks, konten, dan kompetensi.

b. Lembar validasi indikator dan tujuan pembelajaran aspek sikap sains terhadap sains melalui telaah konteks, konten, dan sikap.

c. Lembar validasi rancangan bahan ajar sel elektrokimia berbasis green chemistry.

Proses validasi dilakukan dengan cara menghadirkan beberapa pakar yang sudah berpengalaman untuk menilai rancangan bahan ajar tersebut. Setiap pakar diminta untuk menilai kelayakan bahan ajar, sehingga selanjutnya dapat diketahui kelemahan dan kekuatan (Sugiyono. 2012: 302). Hasil validasi dari para pakar kemudian dihitung dengan indeks Content validity Ratio (CVR).

CVR merupakan indeks untuk menyatakan keshahihan berdasarkan validasi isi secara kuantitatif. Validasi isi berkenaan dengan kevalidan suatu alat ukur dipandang dari segi isi (content) materi pelajaran yang melibatkan para pakar keilmuan kimia untuk menilai. CVR ditentukan dengan menggunakan persamaan 1 .

$\mathrm{CVR}=\frac{n e-N / 2}{N / 2}$

(Lawshe.1975: 576)

Keterangan :

ne : banyaknya pakar yang sepakat

$\mathrm{N}$ : banyaknya pakar yang memvalidasi

Setelah mengidentifikasi sub pertanyaan pada lembar validasi dengan menggunakan CVR, kemudian dihitunglah CVI (Content Validity index). Secara sederhana CVI merupakan rata-rata dari nilai CVR untuk sub pertanyaan yang dijawab Ya.

Perolehan CVI diperoleh dengan menggunakan persamaan 2 .

$$
\mathrm{CVI}=\frac{\sum C V R}{\text { Jumlah subpertanyaan }}
$$

(Alahyari.2011:10)

\section{HASIL DAN PEMBAHASAN}

Kualitas suatu materi subjek dapat dikaji dengan mengemukakan analisis wacana. Analisis wacana didefinisikan sebagai kajian yang meneliti dan menganalisis bahasa yang digunakan secara ilmiah. Analisis wacana digunakan untuk mengetahui kedalaman dan keluasan materi subjek yang dikaji (Herlanti, et al., 2008: 3).

Analisis wacana merupakan tindakan yang dilakukan terhadap wacana teks dari berbagai sumber dalam rangka pengembangan bahan ajar, seperti penulisan buku teks, pengembangan media pembelajaran, penyusunan rencana pembelajaran dan pembuatan soal-soal evaluasi/asesmen. Analisis tersebut dilakukan sebagai langkah sistematis dalam mendalami sumbersumber bahan bacaan, baik berupa buku ajar atau deskripsi dari kegiatan pembelajaran terdahulu. Dalam penulisan buku teks, analisis diperlukan agar proses penulisan buku teks tersebut dapat dilakukan secara efisien dan penyampaian pengetahuan dapat terkendali dari segi konten dan konteksnya.

Buku teks mempunyai peranan penting karena dalam lingkungan membaca, fungsi guru seolah-olah diperankan oleh buku teks dalam bentuk tindakan wacana dengan target pengetahuan materi-subyek dan diarahkan kepada pembaca untuk direspon berupa inteligibel (mudah dijangkau karena konsisten dengan pengetahuan yang telah dimiliki), plausibel (dipahami karena dapat diterapkan secara terbatas pada konten pengetahuan yang dihadapi), atau fruitful (bernilai lebih dari pengetahuan yang sudah dipahami karena ringkas dan berguna). Dalam lingkungan kelas, fungsi guru memfasilitasi proses belajar siswa melalui tindakan wacana yang sedapat mungkin mudah diajarkan (teachable) dan mudah dijangkau (accesible). Analisis wacana dikembangkan sebagai kerangka untuk mewadahi berbagai metodelogi yang digunakan untuk membentuk hubungan ketergantungan antara pengajar, pembelajar, dan $\mathrm{ma-}$ teri-subyek (buku).

Analisis wacana dalam pembuatan buku merupakan fasilitas untuk mengendalikan hubungan terhadap wacana teks dari berbagai sumber dalam rangka pengembangan bahan ajar. Konstruksi pengetahuan sebagai interaksi antara pengajar dan pembelajar menggunakan materisubyek (buku) sebagai media interaksi. Esensi dari interaksi tersebut adalah tindakan wacana berupa menginformasikan, mendalami, mengarahkan, dan membatasi. Tetapi sebagai interaksi, tindakan wacana ini juga perlu dilihat dari segi motif yang mengendalikannya agar memungkinkan pengungkapan sampai kepada menurunkan struktur wacana dari proses mengkonstruksi tersebut. 
Salah satu langkah yang dilakukan pada analisis wacana adalah menyiapkan teks dasar. Teks dasar dibuat dengan melakukan penghalusan terhadap teks sumber untuk memapankan dan menajamkan peran wacananya, melalui:

\section{1. penghapusan atau}

2. penyisipan kata atau frasa.

Penghalusan teks dilakukan dalam rangka meningkatkan ketepatan dan kejelasan teks. Siregar (Setiadi, et al. 2004) menjelaskan bahwa kriteria ketepatan merujuk pada peristilahan yang tidak berlebihan (overstatement) atau kurang memadai dalam mengukuhkan atau menyangkal suatu kebenaran fenomena. Sedangkan kejelasan merujuk pada penggunaan tindakan verbal sehubungan dengan predikat utama yang mengendalikan suatu proposisi.

Penghalusan teks bertujuan untuk membantu pembaca, sesuai dengan karakter atau tingkat kemampuannya, dalam memaknai fungsi wacana melalui pengendalian kalimat topik untuk memelihara pertautan antara satu kalimat dengan kalimat lainnya pada suatu paragraf. Penghapusan teks dilakukan terhadap kata yang diulang atau berlebihan tanpa mengurangi makna dari kalimat sebelumnya, sedangkan penyisipan dilakukan dengan memasukan kata atau frasa tertentu untuk memapankan maknanya. Agar makna wacana dapat tetap terpelihara, maka dalam melakukan penghalusan teks sebaiknya terlebih dahulu diidentifikasi tindakan eksplanasinya pada tingkat paragraf.

Dalam menyusun sekuensi wacana bahan ajar yang mengandung muatan literasi sains maka dilakukan modifikasi tahapan-tahapan pembelajaran proyek Chemie im Kontext dalam Nentwig, et al., (2002) dan penyisipan langkah seperti yang disarankan oleh Holbrook (2005). Sekuensi wacana bahan ajar diperoleh sebagai berikut ini.

1. Tahap Kontak (Contact Phase). Pada tahap ini dikemukakan isu-isu, masalah yang ada di masyarakat atau menggali berbagai peristiwa yang terjadi di sekitar siswa dan mengaitkannya dengan materi yang akan dipelajari sehingga siswa menyadari pentingnya memahami materi tersebut. Topik yang dibahas dapat bersumber dari berita, artikel, atau pengalaman siswa sendiri.

2. Tahap Kuriositi (Curiosity Phase). Pada tahap ini dikemukakan pertanyaanpertanyaan, dimana jawabannya membutuhkan pengetahuan sains yang dapat men- gundang rasa penasaran dan keingintahuan siswa.

3. Tahap Elaborasi (Elaboration Phase). Pada tahap ini dilakukan eksplorasi, pembentukan dan pemantapan konsep sampai pertanyaan pada tahap kuriositi dapat terjawab. Eksplorasi, pembentukan dan pemantapan konsep tersebut dapat dilakukan dengan berbagai metode, misalnya ceramah bermakna, diskusi dan kegiatan praktikum, atau gabungan dari ketiganya. Melalui kegiatan inilah berbagai kemampuan siswa akan tergali lebih dalam, baik aspek pengetahuan, keterampilan proses maupun sikap dan nilai.

4. Tahap Pengambilan Keputusan (Decision Making Phase). Pada tahap ini dilakukan pengambilan keputusan bersama dari permasalahan yang dimunculkan pada tahap kuriositi. Dengan begitu, penyelesaian dari permasalahan yang muncul tersebut jelas dan benar-benar dapat dipahami oleh siswa tanpa ada keraguan.

5. Tahap Nexus (Nexus Phase). Pada tahap ini dilakukan proses pengambilan intisari (konsep dasar) dari materi yang dipelajari, kemudian mengaplikasikannya pada konteks yang lain (dekontekstualisasi), artinya masalah yang sama diberikan dalam konteks yang berbeda dimana memerlukan konsep pengetahuan yang sama untuk pemecahannya. Tahap ini dilakukan agar pengetahuan yang diperoleh lebih aplikatif dan bermakna di luar konteks pembelajaran.

Setelah mengacu pada teks sequence map yang telah dirancang d iatas dilakukanlah proses komposit konten-konteks. Secara umum, komponen yang terdapat pada sel elektrokimia dengan baterai Li-ion adalah sama yaitu terdiri atas anoda, katoda dan elektrolit. Sehingga proses komposit konten sel elektrokimia dan konteks baterai Li-ion dilakukan berselang-seling. Proses komposit konten-konteks ini menghasilkan draft bahan ajar sel elektrokimia berbasis green chemistry. Selanjutnya untuk mengetahui kelayakan terhadap bahan ajar tersebut dilakukan penilaian oleh tujuh orang validator.

Penilaian terhadap bahan ajar secara keseluruhan meliputi lima poin penilaian, yaitu : (1) Ketepatan materi (konten dan konteks), (2) Kesesuaian antara konten dan konteks, (3) Kesesuaian materi dengan kurikulum (tujuan pembelajaran), (4) Ketepatan ilustrasi 
gambar/simbol/ sketsa/percobaan, dan (5) Kesesuaian materi dengan kemampuan siswa SMA. Berdasarkan poin penilaian tersebut maka diperoleh CVI untuk bahan ajar ini adalah 0.86. Interpretasi dari nilai CVI ini menandakan bahwa bahan ajar yang dihasilkan layak untuk siswa SMA.

Tujuan pembelajaran yang telah ditetapkan ditransformasi ke dalam langkah-langkah pembelajaran STL yang mengadopsi tahaptahap pembelajaran berdasarkan proyek Chemie im Kontext dalam Nentwig et al. (2002) dan Holbrook (2005. Tahapan itu meliputi: tahap kontak, kuriositi, elaborasi, decission making, nexus (dekontekstualisasi dan rekontekstualisasi). Dengan menggunakan tahap-tahap pembelajaran STL tersebut, diharapkan siswa dapat mengembangkan proses berpikir mereka karena dihadapkan pada permasalahan tentang bagaimana baterai Li-ion dapat dijadikan sumber listrik alternatif masa depan yang ekonomis dan ramah lingkungan. Permasalahan tersebut disajikan pada tahap kuriositi dan memerlukan jawaban sebagai penyelesaian masalah pada tahap decission making. Langkah-langkah pembelajaran STL tersebut dituangkan menjadi suatu peta langkah-langkah penyusunan teks bahan ajar yang disebut sebagai text sequence map. Isu lingkungan yang dimunculkan pada tahap kontak meliputi:isu pencemaran lingkungan, limbah, suistainable development, baterai ramah lingkungan dan baterai beracun.

\section{KESIMPULAN}

Pengembangan bahan ajar sel elektrokimia menggunakan model rekonstruksi pendidikan melalui 3 tahapan, yaitu :1). Analysis of Content structure, 2). Empirical investigation, and 3). Construction of instruction. Ketiga komponen ini saling berkaitan membentuk hubungan cyclic yang dapat berulang (recursive). Penilaian terhadap bahan ajar secara keseluruhan meliputi lima poin penilaian, yaitu : (1) Ketepatan materi (konten dan konteks), (2) Kesesuaian antara konten dan konteks, (3) Kesesuaian materi dengan kurikulum (tujuan pembelajaran), (4) Ketepatan ilustrasi gambar/ simbol/ sketsa/ percobaan, dan (5) Kesesuaian materi dengan kemampuan siswa SMA. Berdasarkan poin penilaian tersebut maka diperoleh CVI untuk bahan ajar ini adalah 0.86. Interpretasi dari nilai CVR ini menandakan bahwa bahan ajar yang dihasilkan layak untuk siswa dikelas.

Analisis empiris melalui wawancara dikategorikan dalam dua bagian, yaitu pertanyaan tentang pra-konsepsi siswa terhadap konsep green chemistry dan pertanyaan mengenai ketertarikan dan sikap siswa terhadap isu green chemistry yang berkembang. Perolehan peningkatan jawaban diperoleh ketika siswa ditanyakan tentang sikap dan ketertarikannya terhadap sains sedangkan pertanyaan tentang isu sosial sains green chemistry menunjukkan bahwa hampir seluruh siswa memiliki prakonsepsi yang salah, sehingga konsep ini perlu dimunculkan dalam bahan ajar.

Berdasarkan hasil analisis penulis terhadap proses pengembangan bahan ajar sel elektrokimia berbasis green chemistry ini, Selanjutnya dapat dilakukan penelitian lanjutan untuk menggunakan bahan ajar ini dalam proses pembelajaran seperti yang terdapat dalam skema model rekonstruksi pendidikan yang ditawarkan oleh Duit, et al., (2012). Shwartz, et al. (2006) telah mengembangkan beberapa penilaian untuk mengukur pencapaian literasi kimia siswa, diharapkan dengan mengkolaborasikan bahan ajar ini dengan model pembelajaran yang lain sebagai perlakuan pembelajaran dapat berkontribusi dalam pencapaian literasi kimia siswa pada level nominal, fungsional, dan konseptual

\section{DAFTAR PUSTAKA}

Allahyari, T., Rangi, N.H., Khosravi, Y., and Zayeri, F. 2011. Development and Evaluating of A New Questionnaire for Rating of Cognitive Failures at Work. IJOH.3:6-11.

Arikunto, S. 2008. Dasar-dasar Evaluasi Pendidikan. Jakarta: Bumi Aksara.

Cann, M. 2009. "Greening the Chemistry Lecturer Curriculum: Now is the time to infuse Existing Mainstream Textbooks with Green Chemistry". Journal of American Chemical Society. 93-100.

Duit, R.1995. A Model of Educational Reconstruction. San Fransisco : Paper of Research in Sains Teaching (NARST).

Duit, R. 2007. Science educational research internationally: Conception, Research method, Domain research. Eurasia jurnal of mathematics. ISSN:1305-8223. 
Duit, R., Gropengierber, H., Kattmann, U., Komorek, M., Parchmann, I. 2012. The

Model of Eductional Reconstruction - A

Framework for Improving Teaching and Learning Science. Science Research and Practice in Europe. ISBN :978-94-6091900-8.

Hayat, B dan Yusuf, S.2010. Mutu Pendidikan. Jakarta: Bumi Aksara.

Holbrook, J. 2009. "Meeting Challenges to Sustainable Development through Science and Technologi Education". Journal of science education international. 20, (1), 44-59.

Klingshirn, M, et al. 2009. "Integrating Green Chemistry into the Introductory Chemistry Curriculum". Journal of American Chemical Society. 79-91

Lawshe. 1975. A Quantitative Approach to Content Validity. Journal Personnel Psycology. 28, 563-575.

OECD 2009. PISA 2009 Assessment Framework Key competencies in reading, mathematics and science. [online].

Tersedia:http:// www.oecd.org/dataoecd/11/40/44455820. pdf [10 September 2012].

Tundo 2001. Green Chemitry Education. Poster presented at the IUPAC congress/General Assembly. 